\title{
A case of synthetic cannabinoid poisoning in Croatia
}

\author{
Davorka Sutlović ${ }^{1,2}$, Ingrid Prkačin ${ }^{3}$, Fabio Vaiano $^{4}$, Elisabetta Bertol ${ }^{4}$, Maja Veršić Bratinčević², \\ and Marija Definis-Gojanović ${ }^{1,2}$
}

Department of Pathology and Forensic Medicine, University Hospital Centre Split ${ }^{1}$, Department Forensic Medicine, University of Split School of Medicine, Split ${ }^{2}$, Clinical Hospital Merkur, Clinic for Internal Medicine, Zagreb ${ }^{3}$, Croatia, Department of Health Science, University of Florence, Florence, Italy ${ }^{4}$

[Received in January 2018; Similarity Check in January 2018; Accepted in May 2018]

\begin{abstract}
The number of new psychoactive substances (NPS), synthetic cannabinoids (SCs) in particular, is growing constantly. Because of the insufficiently explored effects on consumer health, they have become a major problem in the emergency departments. They are difficult to identify, and there are no antidotes that could reverse their detrimental effects. We report a case of poisoning of a young man who used SCs. The patient was admitted to the emergency department of the Clinical Hospital Merkur, Zagreb (Croatia) after sniffing and smoking a herbal product bought on the street. He presented with severe cognitive difficulties and visible eye redness. Other symptoms included somnolence, disorientation, loss of coordination, unsteady gait, hyporeflexia, stiffness, cramps and cold limbs, blurred vision, teeth grinding, dry mouth, tinnitus, fear, suicidal thoughts, impaired focus, memory, and speech, sedation, fatigue, depression, thought blocking, and autistic behaviour. His skin was dry, and his mucosa dry and irritated. Herbal products "Rainbow Special" and "Luminated Aroma" used by the patient were qualitatively analysed with gas chromatography / mass spectrometry (GC/ MS) after direct extraction with an organic solvent. Solid-phase extraction method was used to analyse serum and urine samples. Despite the negative findings of biological samples, mostly due to the limitations of GC/MS, the clinical picture infallibly pointed to the poisoning with SCs. This was confirmed by the findings of 5-fluoro AMB (methyl 2-(1-(5-fluoropentyl)-1H-indazole-3-carboxamido)-3-methylbutanoate) in the herbal products.
\end{abstract}

KEY WORDS: 5F-AMB; emergency medicine; GC/MS analysis; new psychoactive substances; synthetic cannabinoids

The so called new psychoactive substances (NPS) are the analogues or chemical derivatives of controlled, illicit drugs designed to produce similar effects but at the same time avoid legal prosecution, as their structure differs from illegal drugs on national lists $(1,2)$.

They have emerged on the European market under the names internet drugs, designer drugs, legal highs, herbal highs, research chemicals, and bath salts (3) over the last decade and are grouped as phenethylamines, piperazines, synthetic cannabinoids, or cathinones.

Generally, the clinical manifestations and symptoms of NPS poisoning include cognitive difficulties, dry mouth, anxiety, panic attacks, eye redness, agitation, nausea, vomiting, tachycardia, dizziness, chest pain, headache, and tinnitus (4). These symptoms usually last 2-6 h after use. Testing on animal models showed that NPS inhalation disrupts endothelial function and vasodilatation, which explains the hypertensive reaction after inhalation (5).

\section{Synthetic cannabinoids}

Synthetic cannabinoids do not necessarily have the same or similar chemical structure as THC, but their structure allows them to bind to the CB1 and CB2 cannabinoid

Correspondence to: Professor Davorka Sutlović, Spinčićeva 1, 21000 Split; Croatia, E-mail:dsutlov@kbsplit.hr receptors, which results in similar effects as those of cannabis (6-8). For now, there are seven main structural groups: naphtoylindoles (e.g. JWH-018, JWH-073 and JWH-398); naphtoylmethyllindoles; naphtoylpyrroles; naphtylmethylindens; phenylacetylindoles (e.g. JWH-250), cyclohexanols (e.g. CP 47,497), and classic cannabinoids (eg. HU-210) (6).

These compounds have become more known to the public after the appearance of the product "Spice", which has become very popular among the young population of drug users (9). They are also known under the names K2, Skunk, Moon Rocks, Galaxy, and Rainbow and usually take the form of a powder, resin, oil, or herbal mixture. The usual way of consumption is smoking. Sometimes they are mixed with marijuana in a joint or, rarely, prepared as an herbal infusion to drink. In smart shops, where they are mostly sold, all packages containing herbal blends (usually weighing 0.5-3 g) say that they are "not for human consumption". The packages, however, do not specify chemical substances and their concentrations and quantities, which is particularly dangerous because their quantities and concentrations may vary a lot in the same product. This is why consumers do not have the same reaction after use, and may even overdose themselves and die.

To address this safety issue, Croatia placed synthetic cannabinoids and other NPS on the list of illegal drugs in 
December 2014. However, the number of new psychoactive substances keeps growing and putting ever greater pressure on the emergency departments $(10,11)$. Physicians who work in emergency services are usually the first contact for patients who need help and have an extremely important role in identifying the problems and providing medical and later psychiatric care.

Patients poisoned with NPS pose a particular challenge, because the culprit substances are difficult to identify (given the emergency department equipment) and the choice of best treatment is challenged.

Here we present a case of synthetic cannabinoid poisoning in a young man.

\section{CASE REPORT}

A 19-year-old man was admitted to the emergency department of the Clinical Hospital Merkur, Zagreb (Croatia) in early 2016. He was brought there from school by ambulance, because the teachers noticed incoherent behaviour and suspected drug abuse. He bought the substance on the street and consumed it by sniffing and smoking. He acknowledged taking such substances regularly for a year.

The clinical picture on admission showed severe cognitive impairment, such as very slow movements and slur, visible eye redness, somnolence, disorientation, loss of coordination, unsteady gait, hyporeflexia, stiffness, cramps, cold limbs, blurred vision, teeth grinding, dry mouth, tinnitus, unexplained fear, suicidal thoughts, loss of focus and memory, fatigue, depression, thought blocking, and autistic behaviour. His skin was dry, and the mucosa were also dry and irritated.

Blood pressure was normal (120/80 $\mathrm{mm} \mathrm{Hg}$ ), but even though ECG did not show tachycardia (below 70 beats per minute), the T-waves were tall in the precordial leads, pointing to an increased sympathetic tone. Laboratory blood serum (complete blood count, electrolytes, coagulation, urea and creatinine, $\mathrm{pH}$, and liver transaminases, alkaline phosphatase, and amylases) and urine tests (qualitative analysis of urine sediment and microscopic examination) were within the reference ranges. Sodium levels were at the lower limit of normal.

After initial opposition, the patient agreed to give blood and urine samples for toxicological analyses. Three sets of samples, one urine and two blood and urine sets, were taken; the first set was sent to the biochemistry laboratory of the Clinical Hospital Merkur for screening for benzodiazepines and opiates with test strips, and the second, blood and urine set, was sent to the Referral Centre of the Clinical Hospital Centre Zagreb to confirm screening test findings with gas chromatography / mass spectrometry (GC/MS). The third, blood and urine set was sent to the Clinical Hospital Centre Split (Split, Croatia) to determine NPS presence with advanced methodology.

The boy's mother volunteered background information, as she found and brought empty bags of the products "Rainbow Special" and "Luminated Aroma" (Figure 1), which she would occasionally notice in her son's room over the last few years. She also noticed that her son had difficulties learning, concentrating, and following the classes at school.

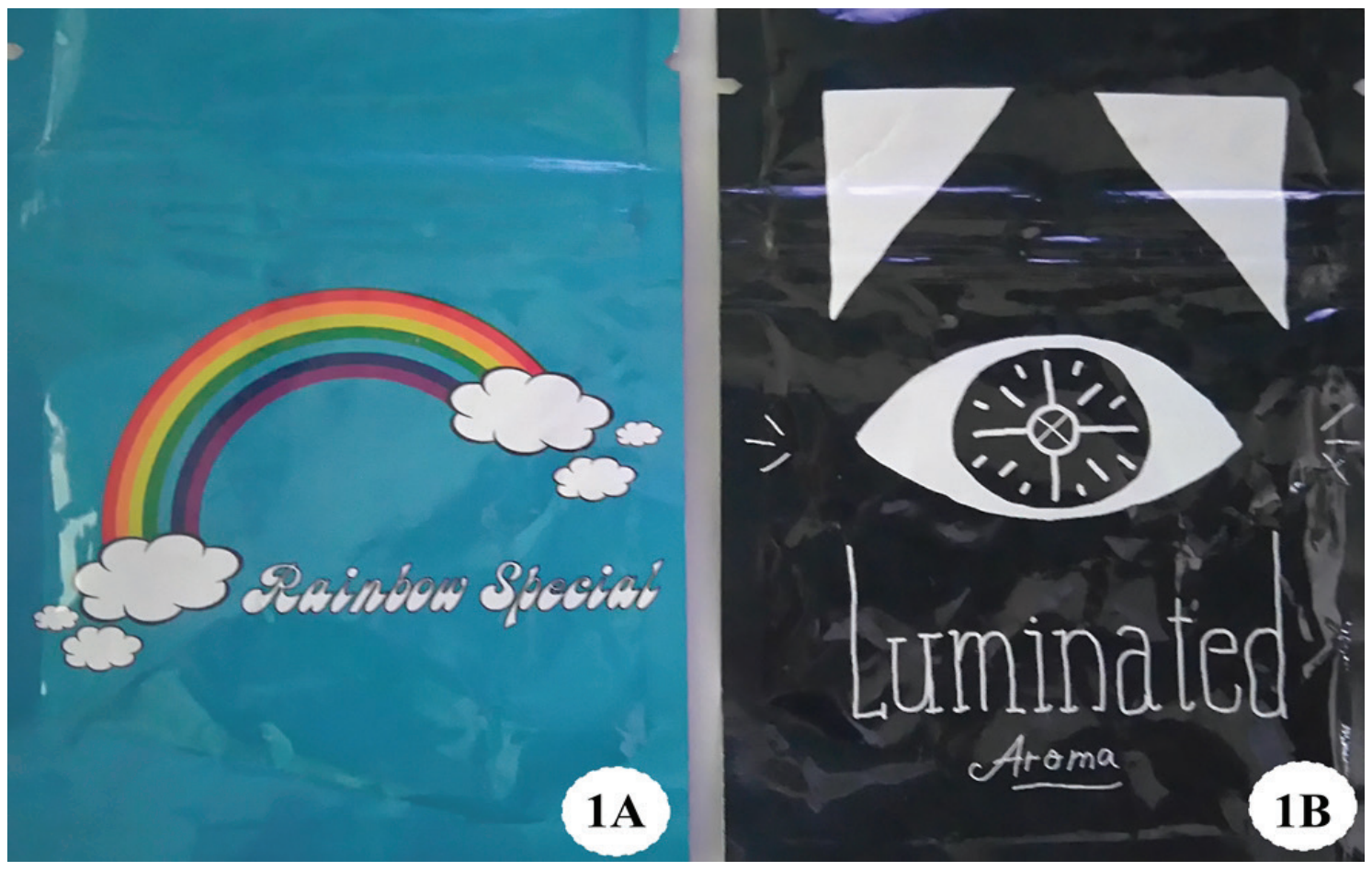

Figure 1 "Rainbow Special" and "Luminated Aroma" with herbal mix traces 
Two bags of the products "Rainbow Special" and "Luminated Aroma" were sent to a laboratory for qualitative analysis with GC/MS.

\section{Biosample analysis}

For both serum and urine extraction we used solid-phase extraction (SPE) with Supelclean Envi Florisil and Supelclean LC-18 Reversed-Phase cartridges (Supelco, Sigma Aldrich, Taufkirchen, Germany) as well as liquidliquid extraction (LLE) with Varian Toxitubes A (Palo Alto, CA, USA). All extraction protocols were carried out according to the manufacturer's instructions.

GC/MS drug analysis was performed on a Shimadzu GC/MS-QP2010 Ultra with a mass spectrometer detector (Shimadzu, Kyoto, Japan). The chromatographic column was InterCap 5MS/NP $5 \%$ phenyl, $95 \%$ methyl polysiloxane, length $30 \mathrm{~m}$, diameter $0.25 \mathrm{~mm}$, film thickness $0.25 \mu \mathrm{m}$ (GL Sciences, Tokyo, Japan). The initial column temperature of $90^{\circ} \mathrm{C}$ was held for $3 \mathrm{~min}$, then ramped to $270{ }^{\circ} \mathrm{C}$ at $15^{\circ} \mathrm{C} \mathrm{min}^{-1}$, held there for $5 \mathrm{~min}$, and then ramped again to $320^{\circ} \mathrm{C}$ at $15{ }^{\circ} \mathrm{C} \mathrm{min}-1$ and held for $27 \mathrm{~min}$. The total run time was $50.33 \mathrm{~min}$. For the carrier gas we used ultrapure-grade helium at the flow rate of about $1.5 \mathrm{~mL} \mathrm{~min}^{-1}$. Samples were injected using the splitless mode with injection temperature of $250^{\circ} \mathrm{C}$. GC/MS analysis was performed using full scan MS (40-600 m/z).

\section{Herbal product analysis}

Before the analysis, the obtained herbal products were subjected to direct extraction with chloroform-ethyl acetate 1:1 (Merck, Darmstadt, Germany). They were macerated for $30 \mathrm{~min}$, filtered, evaporated in nitrogen stream, and dissolved in $30 \mu \mathrm{L}$ of chloroform. The drugs were analysed with a Shimadzu GC-2010 GC/MS with a mass spectrometer detector. The chromatographic column was RTX-5MS $5 \%$ diphenyl, $95 \%$ dimethyl polysiloxane, length $30 \mathrm{~m}$, diameter $0.25 \mathrm{~mm}$, film thickness $0.25 \mu \mathrm{m}$ (Restek, Bellefonte, PA, USA). The initial column temperature of $90{ }^{\circ} \mathrm{C}$ was held for $3 \mathrm{~min}$ and then ramped to $270{ }^{\circ} \mathrm{C}$ at $20{ }^{\circ} \mathrm{C} \mathrm{min}-1$ and held there for $33 \mathrm{~min}$. The total run time was $45 \mathrm{~min}$. For the carrier gas we used ultra-pure-grade helium at the flow rate of about $1.5 \mathrm{~mL} \mathrm{~min}^{-1}$. Samples were injected using the splitless mode with injection temperature of $250^{\circ} \mathrm{C}$. GC/MS analysis was performed using full scan MS (40-600 m/z).

Samples were qualitatively analysed with GC/MS using the full-scan mode. The readings were compared with the Wiley library of Mass Spectra of Designer Drugs (12), the free database of the Scientific Working Group for the Analysis of Seized Drugs (SWGDRUG) (13), as well as with our in-house library containing about 1000 compounds and metabolites. Each sample was analysed twice. To verify the findings, the chromatograms were sent to the University of Florence Department of Health Science, Florence, Italy.

\section{Results}

The urine screening test was negative for the presence of benzodiazepines and opiates. Blood and urine tests were negative for alcohol.

The GC/MS also found no presence of the common illicit drugs.

However, the GC/MS of the herbal products (Figure 1) determined the presence of synthetic cannabinoid 5-fluoro AMB (methyl 2-(1-(5-fluoropentyl)-1H-indazole-3carboxamido)-3-methylbutanoate; $5 F-A M B$ ) (Figure 2).

After supportive therapy (1500 $\mathrm{mL}$ infusion of saline) and six hours of observation at the emergency department, the patient was discharged in the company of his mother. He was stable, and his blood pressure and heart rate normal. He was referred to a psychiatrist for further therapy.

\section{DISCUSSION}

The main limitation of our study is related to the use of the screening test strips and the GC/MS, neither of which could precisely characterise the substance(s) responsible for the patient's poisoning in the tested biological samples. At the same time, synthetic cannabinoid 5F-AMB was found in the herbal products obtained from the patient's mother. The GS/MS reading was compared with the readings of 64 NPS reference materials reported by Vaiano et al. (14).

The same synthetic cannabinoid, 5F-AMB, was detected in a seized material in Croatia in July 2015 and was added to the European information system and database on new drugs (EDND) shortly afterwards (15). According to reports from other European countries that are available on the European Monitoring Centre for Drugs and Drug Addiction (EMCDDA) website, this substance had already been seized and described in 2014 (16).

Literature data originating from $2015(17,18)$ report the presence of 5F-AMB in the biological samples (adipose tissue and femoral blood) taken during the autopsy of a synthetic cannabinoid poisoning victim.

Andersson et al. (19) determined 17 metabolites of $5 \mathrm{~F}-\mathrm{AMB}$ in vitro and reported that the microsomal half-life and intrinsic clearance of 5F-AMB are very short. In other words, it metabolises rapidly. This is one of the reasons why it cannot be proven in biological samples, especially in the clinical ones after a short while and the most likely reason why we did not detect it in the biological samples collected from our patient. In such cases, the analysis of suspected products, if available, may help to point the physician in the right direction for treatment. Another helpful pointer would be an atypical clinical picture, especially in younger patients, as it raises suspicion of NPS consumption (11). 


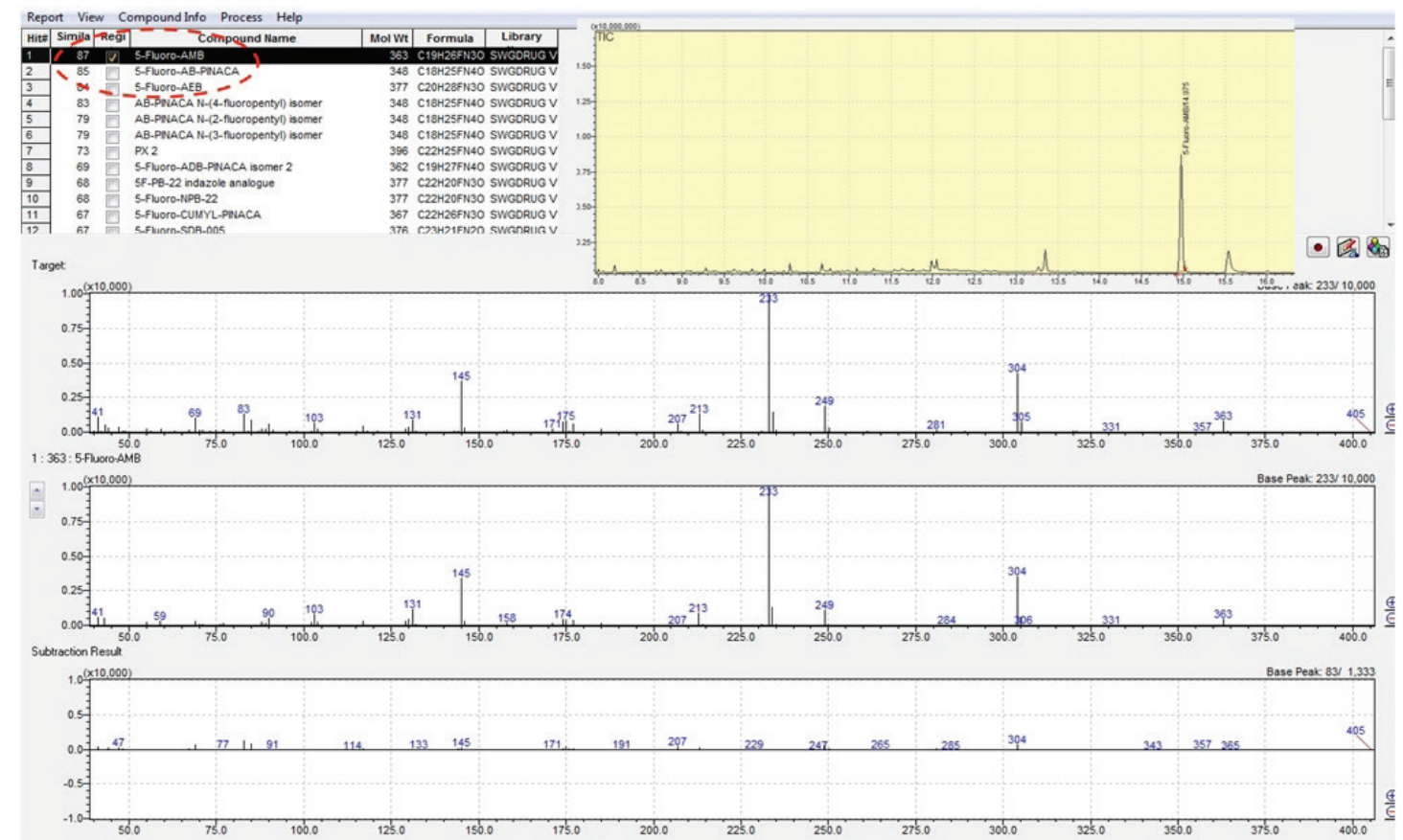

Figure 2 Total ion chromatogram of the herbal bag content and the characteristic spectra of $5 F-A M B$ matched to the SWGDRUG database (13)

\section{CONCLUSION}

The clinical picture presented here and circumstantial evidence (herbal product brought by the mother) pointed to the consumption of synthetic cannabinoids but it was not confirmed by laboratory findings. Obviously, prompt recognition and treatment of NPS poisoning represents a major challenge both for the healthcare professionals and toxicologists. To efficiently manage such cases, it is very important to collect information about possible use of psychoactive substances in addition to observing clinical manifestations in the patient. It is also very important to build a quality network as part of the national early warning system that would include emergency services, primary health care, and toxicology laboratories that own advanced equipment for NPS determination. This would improve diagnosis, and possibly lead to an NPS database with symptoms related to a specific substance that would be available to all interested healthcare professionals.

\section{REFERENCES}

1. European Monitoring Centre for Drugs and Drug Addiction (EMCDDA) and Europol. EU Drug Markets Report: Strategic Overview. Luxembourg: EMCDDA, Europol; 2016. doi: $10.2810 / 216248$

2. Vlada Republike Hrvatske. Protokol o nacionalnom informacijskom sustavu za droge u Republici Hrvatskoj [Croatian Protocol on the National Information Drugs System, in Croatian]. Zagreb: Ured za suzbijanje zlouporabe opojnih droga, Nacionalna informacijska jedinica za opojne droge; 2007.
3. United Nations Office on Drugs and Crime. The challenge of new Psychoactive substances, Global SMART Programme, 2013 [displayed 14 May 2018]. Available at https://www. unodc.org/documents/scientific/NPS_Report.pdf

4. Centers for Disease Control and Prevention. Opioids drive continued increase in drug overdose deaths [displayed 20 February, 2013]. Available at http://www.cdc.gov/media/

5. Pinnamanemi K, Sievers RE, Sharma R, Selchau A M, Gutierrez G, Nordsieck EJ, Su R, An S, Chen Q, Wang X, Derakhshandeh R, Aschbacher K, Heiss C, Glantz SA, Schick SF, Springer ML. Brief exposure to secondhand smoke reversibly impairs endothelial vasodilatory function. Nicotine Tob Res 2014;16:584-90. doi: 10.1093/ntr/ntt189

6. ACMD. Consideration of the major cannabinoid agonists, 2009 [displayed 14 May 2018]. Available at http://www. namsdl.org/library/E2E 91 AB $8-1372-636$ C DDFC2BA64093B64C/

7. European Monitoring Centre for Drugs and Drug Addiction (EMCDDA) and Europol. EU Drug Markets Report: InDepth Analysis. Lisbon: EMCDDA, Europol; 2016.

8. Dargan PI, Wood DM, editors. Novel Psychoactive Substances: Classification, Pharmacology and Toxicology. London: Academic Press/Elsevier; 2013. doi: 10.1016/ C2011-0-04205-9

9. Baumeister D, Tojo LM, Tracy DK. Legal highs: staying on top of the flood of novel psychoactive substances. Ther Adv Psychopharmacol 2015;5:97-132. doi: $10.1177 / 2045125314559539$

10. Katselou M, Papoutsis I, Nikolaou PD, Spiliopoulou C, Athanaselis S. $\alpha$-PVP ("flakka"): a new synthetic cathinone invades the drug arena. Forensic Toxicol 2016;34:41-50. doi: 10.1007/s11419-015-0298-1

11. Rojek S, Klys M, Maciow-Glab, Kula K, Strona M. Cathinones derivatives-related deaths as exemplified by two fatal cases involving matcathinone with 4-methylmatcathinone 
and 4-methylethcathinone. Drug Test Anal 2014;6:770-7. doi: $10.1002 /$ dta. 1615

12. Rösner P, Junge T, Westphal F, Fritschi G. Mass Spectra of Designer Drugs 2015. Weinheim: Wiley; 2015.

13. Scientific Working Group for the Analysis of Seized Drugs (SWGDRUG). Mass Spectral Library [displayed 23 May 2018]. Available at http://www.swgdrug.org $/ \mathrm{ms} . \mathrm{htm}$

14. Vaiano F, Busardò FP, Palumbo D, Kyriakou C, Fioravanti A, Catalani V, Mari F, Bertol E. A novel screening method for 64 new psychoactive substances and 5 amphetamines in blood by LC-MS/MS and application to real cases. J Pharmaceut Biomed 2016;129: 441-9. doi: 10.1016/j. jpba.2016.07.009

15. European Monitoring Centre for Drugs and Drugs Addiction (EMCDDA). European information system and database on new drugs [displayed 23 May 2018]. Available at https:// ednd-cma.emcdda.europa.eu/

16. European Monitoring Centre for Drugs and Drug Addiction (EMCDDA). European Drug Report: Trends and
Developments 2014. Lisbon: EMCDDA; 2014. doi: $10.2810 / 32306$

17. Hasegawa K, Wurita A, Minakata K, Gonmori K, Nozawa H, Yamagishi I, Watanabe K, Suzuki O. Postmortem distribution of AB-CHMINACA, 5-fluoro- AMB, and diphenidine in body fluids and solid tissues in a fatal poisoning case: usefulness of adipose tissue for detection of the drugs in unchanged forms. Forensic Toxicol 2015;33:4553. doi: 10.1007/s11419-014-0245-6

18. Hess C, Stockhausen S, Kernbach-Wighton G, Madea B. Death due to diabetic ketoacidosis: Induction by the consumption of synthetic cannabinoids? Forensic Sci Int 2015;257:e6-11. doi: 10.1016/j.forsciint.2015.08.012

19. Andersson M, Diao X, Wohlfarth A, Scheidweiler KB, Huestis MA. Metabolic profiling of new synthetic cannabinoids AMB and 5F-AMB by human hepatocyte and liver microsome incubations and high-resolution mass spectrometry. Rapid Commun Mass Sp 2016;30:1067-78. doi: $10.1002 / \mathrm{rcm} .7538$

\section{Slučaj trovanja sintetskim kanabinoidima u Hrvatskoj}

Broj novih psihoaktivnih tvari (engl. new psychoactive substances, krat. NPS), osobito sintetskih kanabinoida (engl. synthetic cannabinoids, krat. SC), stalno se povećava. Zbog nedovoljno istraženih učinaka na zdravlje korisnika, te tvari stvaraju velike probleme odjelima hitne medicine. Teško je dokazati njihovu prisutnost, a protuotrovi koji bi mogli poništiti njihovo štetno djelovanje nisu poznati. Prikazujemo slučaj trovanja mladog muškarca koji je konzumirao sintetske kanabinoide. Pacijent je zaprimljen na odjel hitne službe Kliničke bolnice Merkur u Zagrebu nakon šmrkanja i pušenja biljnog proizvoda kupljenoga na ulici. Prilikom dolaska u hitnu službu kliničkom slikom dominiraju kognitivne poteškoće (izrazito usporenih kretnji, polaganog izgovora), a objektivno je bilo uočljivo izrazito crvenilo očiju. Klinička slika bolesnika uključivala je niz različitih simptoma: stanje svijesti - somnolencija; neurološki simptomi - dezorijentiranost, gubitak koordinacije, nesiguran hod, hiporefleksija; oftalmološki simptomi - zamagljen vid; ORL simptomi - škripanje zubima, suha usta, šumovi u ušima; simptomi srca, krvožilja i dišnog sustava - nije imao; simptomi probavnog sustava - gubitak apetita; simptomi mišićno-koštanog sustava - ukočenost, grčevi i hladnoća udova; psihološki simptomi konfuzija, strah, suicidalne misli, poremećaj pažnje, pamćenja i govora, sedacija, umor, depresija, blok misli, autistično ponašanje. Koža je bila suha, a sluznice suhe i iritirane. Heteroanamnestičkim podacima od majke, koja je donijela prazne vrećice marketinškog imena Rainbow Special i Luminated Aroma doznali smo da slične vrećice nalazi već godinu dana u sinovoj sobi, a istom zamjećuje da sin sve teže uči, ne može se koncentrirati i pratiti nastavu. Sin je odbijao prestati s konzumacijom. Biljni proizvodi Rainbow Special i Luminated Aroma, koje je pacijent konzumirao nakon izravne ekstrakcije s organskim otapalom, kvalitativno su analizirani plinskom kromatografijom / masenom spektrometrijom (GC / MS). Metodom ekstrakcije na čvrstoj fazi analizirani su uzorci seruma i mokraće. Unatoč negativnim nalazima bioloških uzoraka, uglavnom zbog ograničenja GC / MS metode, klinička je slika nedvojbeno upućivala na trovanje sintetskim kanabinoidima. To je potvrđeno i nalazima 5-fluor AMB (metil 2- (1- (5-fluoropentil) -1H-indazol-3-karboksamido) -3-metilbutanoata) u biljnim proizvodima.

KLJUČNE RIJEČI: 5F-AMB; GC / MS analiza; hitna medicina; Luminated Aroma; nove psihoaktivne tvari; Rainbow Special 